\title{
Institutional Change, Path Dependence and the Rural Land Three Rights Division
}

\author{
Dunyou Shi \\ School of Economics \\ Sichuan University \\ Chengdu, China 610065
}

\begin{abstract}
The three rights division of rural land is another major institutional innovation in the rural land reform following the family contract responsibility institution under the new historical conditions. The core of the rural land three rights division lies in the pursuit of the agricultural economic performance, but the path dependence is an obstacle in promoting the rural land three rights division. Therefore, this article first elaborates the nature of the institutional change and the path dependence, which is efficiency optimization. Then it points out that the institutional change and the economic performance are the inherent motive force for the rural land three rights division. Finally, this article provides some solutions for the path dependence of the rural land three rights division.
\end{abstract}

Keywords-rural land three rights division; Institutional change; path dependence; efficiency optimization

\section{INTRODUCTION}

The Report on the nineteenth National People's Congress of the Communist Party of China has pointed out that we should consolidate and improve the rural basic operation institution, deepen the reform of the rural land institution and improve the three rights division institution of the contracted land. The three rights division of the rural land is considered as the second innovation of rural land institution in China, which achieves the separation of the contract right and the management right, and forms the three rights division of the ownership, contract right and management rights (Yin Chengjie, 2017). Some local governments don't dare to innovate and hang back in practice; at the same time, the academic circles have some different understanding and vague attitudes (Chen Chaobing, 2016; Sun Xianzhong, 2016). Especially, there is a great difference between the new nature of the farmers household contract right and the rural land management right (Cai Lidong and Jiang Nan, 2015; Gao Fei, 2016; Gao Shengping, 2017; Geng Zhuo, 2017). All these are the typical problems existing in the rural land three rights division.

One of the important factors that arises with these issues in theory and practice is that some local officials and farmers worry about the risk of reform and the damage to their own interests from the rural land two rights division to the rural land three rights division, which leads to a gap between the reform results and the top design goals (Wu Shanlin, 2017).
Therefore, we should study the three rights division of rural land based on the perspective of the institutional change and the path dependence.

\section{ThE NATURE OF InStitutional CHANGE AND PATH DEPENDENCE: EFFICIENCY OPTIMIZATION}

Ronald Harry Coase (1960) has elaborated the significance of transaction costs and property rights to economic structure and operation, and he is the first one creatively explaining the reasons for the existence of the enterprise and the boundary problems of the enterprise expansion by putting forward the transaction costs. The paper points out if the transaction costs is zero or very small, and the definition of property rights is clear, then the law will not affect the contract results. According to Coase's property theory, the minimum cost of the property right form that we solve the problem is effective, namely competition will make the efficient economic organization form instead of the inefficient economic organization form in a world of scarcity and competition under the constraints of current technologies, information costs and future uncertainties. Therefore, human beings are working hard to reduce the transaction costs. The theory of property right makes Coase become the founder of the new institutional economics.

A key point of the new institutional economics is to study the relationship between the institutional change and the economic performance, which is to explain the development and change process of economy and society by the institutional change (North et al., 1990). The so-called institutional change refers to a dynamic process of generating, replacing or changing the old institution by the new institution or the new institutional structure. As a production process, the institutional change is a more efficient process of institutional innovation. As an alternative process, the institutional change is a new more efficient institution instead of the original institution. As a change process, the institutional change is the process of changing the old institution. Specifically, the institution can be regarded as a public product, which is produced by individuals or organizations. This is the supply of the institution. Because of the limited rationality and scarcity of resources, the supply of the institution is limited and scarce. With the change of the external environment and the improvement of its own rationality, people will continue to demand the new 
institution in order to achieve the expected increasing income. The institution is stable when the supply and demand of the institution is basically balanced; the change of the institution will occur when the current institution cannot meet the needs of people. The ratio between the costs and the profits of institutional change plays a key role in promoting or inhibiting the institutional change. Only when the expected return is greater than the expected costs, will the actor drive the institutional change. The institutional change is divided into two types, which are the bottom-up institutional change and the top-down institutional change. The bottom-up institutional change is also called the induced institutional change that individuals or a group of people are tempted by the new institution of profit-making opportunities and is spontaneously advocated, organized and implemented. The top-down institutional change is also known as mandatory institutional change that the governments act as the lead and guide working by means of the form of government order and legal form.

Technological progress is an endogenous force in promoting the institutional change. The increase of technical progress rate derives from economy's scale, externality, technological innovation and the reduction of transaction costs. Although the social return rate of the developmental new technology is always high, the development pace of the new technology was very slow in history. The problem is that in addition to the definition of technological innovation property, some technological innovations also need certain cost, and are difficult to obtain some reward for innovation in short term. In addition the innovation is faced with the risks of being imitated and studied. Finally, the institutional change has a self-strengthening mechanism. When such a mechanism makes the institutional change take a certain path, its established direction will be self-strengthening in the future development process, which may either go into a virtuous circle and be rapidly optimized, or may slide down the wrong path, even be locked in a state of ineffectiveness. Therefore, under the balance between the old institutional interests and the new institutional interests, it is an obstacle for the institutional change that some people insist on the path dependence formed by the old institution.

In a word, the path dependence has a strong restraining effect on the institutional change, and it is the key factor affecting economic growth and efficiency optimization. If the path choice is correct, the institutional change will speed up along the predetermined direction, and can greatly arouse people's enthusiasm, make full use of the existing resources to maximize revenue, promote market development and economic growth, which in turn have become an important force to promote the further institutional change. The two sides show a benign circular pattern of mutual causation and mutual promotion, otherwise the opposite. Therefore, it is an inevitable choice to comply with the economic development in the new normal state to determine the allocation of resources by the market and take economic efficiency as the guidance. At the same time, to change the institution that is not suitable for the current economic development adapts to the needs of economic development, which is an effective way to solve the path dependence in the new normal economy.

\section{THE RURAL LAND THREE DIVISION: INSTITUTIONAL CHANGE AND ECONOMIC PERFORMANCE}

When profitability cannot be realized within the current arrangements, it will lead to the formation of a new institutional arrangement. The reason for forming a new institutional arrangement is nothing less than the following two situations, which of one is innovation to change the potential profits, and the other is to reduce the innovation cost and make the change cost-effective (Coase et al., 1991). Therefore, the equilibrium state of the institution is possible at any time. It is the change of cost and profit that leads to the imbalance of the institution and induces to another change of arrangement. The essence of rural land three rights division is the pursuit of the agricultural economic efficiency. Therefore, the change of rural land institution is also no exception and always follows the mode of China's reform and innovation. Since the reform and opening up, the reform of the rural land institution has showed the significant institutional features from the rural land two rights division to the rural land three rights division. The pursuit of market economy performance is the external force of the rural land three rights division, and the intrinsic motivation of it is driven by technological progress.

From the highly concentration of ownership and management right during the people's communes, to the two rights division which is the collective ownership and the family contract management right during the family contract responsibility institution, and to the rural land three rights division which is the ownership, contract right and management right at present, the gradual change of the rural land institution is very obvious in China after nearly 70 years of reform and practice. The reform and practice have gone through three stages from the public ownership and the public management, to the public ownership and the private management, and to the public ownership and the comanagement. It can be expected that the implementation of the rural land three rights division at current will be able to effectively change the disadvantages of the foregone rural land rights structure and institution which is the heavy efficiency and the light fairness, the heavy use and the light ownership, the heavy contracted management right and the light other rights since the reform and opening up implemented. The reform of China's rural land institution has effectively promoted the development of modern agriculture and obviously activated the rural economy under the rural land three rights division. In particular, it accelerates the structural reform of the agricultural supply-side, provides a solid institutional guarantee for improving agricultural efficiency and enhancing agricultural competitiveness and shows obvious institutional performance.

Specifically, the rural land three rights division will have a profound impact on promoting the land intensive management, improving the land use efficiency, liberating the rural labor force and increasing the farmers' property income and so on. First, the rural land three rights division will be beneficial to the rural land scale and intensive 
production and management, the formation and development of various new management organizations in rural areas, the development of agricultural modernization, greatly improving the efficiency of agricultural production and strong protection of national food security. Secondly, the concentration management of the rural land and the improvement of the production efficiency will be beneficial to further transfer and liberate the rural labor force, so that a large number of rural labor achieve reemployment in the modern agricultural management organization, which reaches a benign interaction between the agricultural modernization and new urbanization and creates favorable conditions for urban and rural residents enjoying fair and unified social security. Finally, it is bound to appear revaluation of the rural land value which will substantially increase the property income of the rural residents from the process of the rural land two rights division to the rural land three rights division. Based on the implementation of the rural land collective ownership, we must stabilize farmers' contracting right and activate land management right, and allow the rural land management right to be mortgaged financing from financial institutions. At present, the contracted land of farmers has more than one billion mu throughout the country. If the land management right can be mortgaged to the financial institutions after the land ownership registration, a large number of farmers will receive huge credit funds to develop their rural production and operation and the market allocation of a variety of production factors can be realized, and the efficiency of the large-scale agricultural production will be greatly improved.

\section{THE OBSTACLES OF THE THREE DIVISION OF RURAL LAND: PATH DEPENDENCE AND SOLUTIONS}

The rural land three rights division is an institutional change process from the household contract responsibility institution by the government led, which is an important breakthrough and significant reform for the past rural land property right institution and management institution, so it must have a feature of the path dependence. On the one hand, the household contract responsibility institution has been carried out for forty years and has become a stable institution for all parties. The farmers enjoy the rural land private property rights by owning the form of the rural land contracting management right. The rural land is an important guarantee for the survival and development of farmers and becomes the cornerstone of social stability in rural areas. The ownership of the collective economic organizations to the rural land is also getting weaker and even fragmented; the collective economic organization has basically lost the motivation and ability of exercising the collective land ownership. Because the local government as the main body of land expropriation is highly dependent on the land finance, the weakening of the rural land collective ownership and the dispersion of the land contractual management right are conducive to the land expropriation. The land use control institution and family business mode have full convergence; the rural land three rights division will increase the complexity of the land management in rural areas. Therefore, as the main body of land management, the local government is lack of the reform's internal incentive of the rural land property institution. On the other hand, the rural land three rights division is a reconstruction of the rural land property rights institution and a new institution design, so the institution design and implementation require large initial investment, including initial property rights definition, remodeling local governance structure, re-establishing the collective economic organizations and the rural land market mechanism and so on. In addition, the rural land three rights division will break the fixed interest distribution pattern related to the rural land, coupled with the risks and uncertainties of the institution, which will be bound to be hindered by the vested interests and generate a great deal of new problems and disputes. At the same time, to complete and solve these problems and work needs to spend a lot of resources, and how a huge initial investment can be distributed among all the parties is also an issue that is not easily solved.

These factors cause the traditional rural land property rights institution which is two rights separation to have strong self-reinforcing mechanism. The reform is just empty talk and the rural land property rights institution will continue to be locked in the traditional inefficient household contract responsibility institution if it cannot break this reinforcing mechanism in the rural land three rights division. Furthermore, the rural land three rights division has a very obvious potential institution income, so the reforms are imperative despite obstacles. However, the existence of contingency factors and transaction costs will play an important even decisive role in the institutional change direction and effect of the rural land three rights division.

\section{CONCLUSION}

Therefore, the following efforts should be made to break down the path dependence in the rural land three rights division. The first one is to implement the gradual reform in practice. The form must be steady. In other words feeling the stones across the river and keeping the reform risk within control in the rural land three rights division are suitable. Otherwise, once the emergence of a widespread and systemic risk appears, the rural land property rights institution will be in low efficiency and even a malignant path of institutional change. The second one is that the innovation is the accelerator of the reform. We should actively study and analyze various transaction costs in the design and implementation process of the new institution, so we must reduce the transaction costs of the new institution, which is an important topic to ensure the effectiveness of the institution, and reduce transaction costs, which is a focal point to break through the path dependence. The third one is to learn from the successful experience of the advanced areas, which is a shortcut to implement the reform. In the implementation process of the rural land three rights division, especially in the implementation process of the central opinions on the land expropriation, the collective commercial construction land into the market and the homestead institution reform pilot work, the pilot areas cannot be behind closed doors, cannot be too aggressive, but cannot do anything. In the process of the pilot reform, we should learn successful experience and mature practices from other pilot 
areas. At the same time, we should also consult experts and scholars about reform issues, and regularly invite experts for guiding and teaching so as to ensure that the risk of the reform is controllable.

\section{REFERENCES}

[1] Cai Lidong, Jiang Nan. Construction of Contract Law and Division of Business Rights [J]. Law Research, 2015,37 (03): 31-46.

[2] Chen Chaobing. "Separation of the Three Powers" in Rural Land: Function, Division of Power and Establishment of Institution [J]. China Population Resources and Environment, 2016,26 (04): 135-141

[3] Coase R. H. The Problem of Social Cost[J]. Journal of Law \& Economics, 1960, 3(4):1-44.

[4] Coase R. H., Alchain A., North D.. Property rights and institutional changes [M]. Shanghai People's Publishing House, 2014.

[5] Gao Fei. Jurisprudence Interpretation and Institutional Implications of the "Separation of the Three Powers" in Rural Land [J]. Law Research, 2016,38 (03): 3-19.

[6] Gao Shengping. Reconstruction of Land Contract Right from the Perspective of Separation of Farmland from Three-Power [J]. Jurisprudence, 2017 (05): 1-12 + 175.

[7] Geng Zhuo. Jurisprudential Reflection and Institutional Response of Land Management Right in the Separation of Three Rights of Farmland [J]. Jurisprudence, 2017 (05): 13-24 + 175 .

[8] North D C. Institutions, institutional change, and economic performance[M]. Cambridge University Press, 1990.

[9] Sun Xianzhong. A Legislation to Promote the Three-Power Management Mode of Rural Land [J]. China Social Sciences, 2016 (07): 145-163 + 208-209.

[10] Wu Shanlin. Separation of powers to make rural land alive [J]. People's Forum, 2017, (08): 52-54.

[11] Yin Chengjie. Separation of Three Powers: A Major Innovation of Farmland Institution [J] .Agricultural Economics, 2017,38 (09): 4-6. 